\title{
From the Centre to the Margins and Back Again: Women in Agriculture at the ILO
}

\author{
Christine Verschuur
}

\begin{abstract}
Women in agriculture play a particularly important role in the economy. But their work - as peasants and as agricultural wage earners - their knowledge, their place in agricultural systems of production and their contribution to global prosperity have only been recognised in recent years, or still lack significant recognition. With changes in systems of production that are related to globalisation, the marginalisation and the workload of women in agriculture has often increased due to the perpetuation of an unequal sexual division of work in agriculture, and due to unequal access to the workforce and to agricultural inputs, technologies, credit schemes and land. One of the main constraints faced by female peasants and agricultural wage earners is the continuous and increasing reproductive work, which rests disproportionately on the most excluded women.
\end{abstract}

Feminist studies have theorised and underlined the centrality of social reproduction, deconstructing what women's work is and contesting the binary distinction between 'production' and 'reproduction'. They have, further, shown how the prosperity of the global economy benefits from women's work, including subsistence production where women play a major role.

The focus on women in agriculture has been a starting point for gender and development studies. The International Labour Organization's (ILO) programmes on women in rural areas have included groundbreaking research, the recognition of women's unpaid and paid work, and support for women's empowerment in grass-roots organisations. After having disappeared to the margins, rural women are back at the centre of the ILO's discussion on rural economies in recent years. The approach is now guided by the Decent Work agenda, which prevails globally in the ILO. We will explore how the ILO's programmes on rural economies and gender have evolved since the Organization's inception. We will also consider how the ILO's analysis and programmes

(C) CHRISTINE VERSCHUUR, 2019 | DOI:10.1163/9789004399013_009

This is an open access chapter distributed under the terms of the prevailing CC-BY-NC license at the time of publication. 
directed at the work of the most excluded women in agriculture could contribute to informing the Decent Work Agenda and changing the organisation of social reproduction and livelihoods.

\section{Introduction}

Rural issues have occupied a central place in the history of Development Studies, and issues regarding women in agriculture have been the starting point in Women/Gender and Development Studies. While the International Labour Organization (ILO) is not the specialised United Nations (UN) agency on rural issues, it has nevertheless also started its pioneering work on gender issues in the UN system by focusing on women's work in agriculture. In this chapter, we will concentrate on one component of rural women's economic participation - their work in subsistence agriculture and as agricultural wage earners - and particularly on marginalised women in rural areas.

In order to situate women in agriculture in the gender and development debate, the chapter starts with a brief history of the understanding of 'development' and the place of rural economies in this discourse and an overview of how the women/gender and development debate has evolved. This requires an intersectional approach to include women who are at the margins-for reasons of class, race, ethnicity, caste or other mutually reinforcing categories of exclusion.

We will then present how, since the ILo's inception, rural issues and an interrogation of women's work in agriculture have gone through ebbs and flows, moving from the centre to the margins and back again in the Organization's work on gender issues.

The field of knowledge on gender and development, which has been constructed with close interaction between scholars, feminist movements and international organisations, has been fuelled by some of the contributions of the ILO. Selected groundbreaking central feminist concepts elaborated on this path will be discussed, in particular women's work and social reproduction. Analysis of women's work in agriculture has been pivotal to the discussion of these concepts, and to understanding the articulation between subsistence production and the global economy and capitalist prosperity (Meillassoux, 1975).

We will conclude with a discussion on how, and if, the ILO's Decent Work Agenda in rural economies takes into account marginalised women in agriculture and how it can contribute to the discussion on the future of work, and to changes in the organisation of social reproduction and livelihoods. 
The protection of wage earners was the target of the ILO at its inceptionthose who operate in the labour market as formal, paid workers. Women's organisations and feminist movements managed to introduce women's issues into the early ILO debates, with contrasting positions on protectionist laws and laws promoting the principle of equality - positions that have continued to influence policy deliberations throughout the history of the ILO (ILO, 2009). At the first International Labour Conference (ILC) in 1919, two of the six conventions adopted concerned women—prohibiting night work for women and ensuring maternity protection for working women.

However, the way in which the ILO's target had been defined meant that the majority of women were not included, since most were not formal, paid workers but rather peasants, informal, home-working, or domestic workers (see, for instance, for France, Maruani and Meron, 2013). With the ILO Declaration of Philadelphia in 1944, independent workers were included as targets, but not informal workers. But even today informal workers constitute the majority of the workers in the world. ${ }^{1}$

In the 1970s, the ILO's definition of informal workers referred to the 'working poor' in urban areas of developing countries, working in very small-scale units, mostly self-employed or with some assistance from family members or hired workers, whose income-generating activities are not registered, recognised or regulated by the government (ILO, 1991a). Rural employment statistics (see Table 8.1) show a large number of 'self-employed' people in agriculture, a small number working in non-agricultural employment, and a significant number of 'non-active' or 'not reported'. The number of wage earners is marginal, particularly in agriculture and specifically among women. The 2002 ILO Resolution concerning decent work and the informal economy included both wage earners and 'own-account workers'-people engaged exclusively in nonmarket production are not taken into account. There is no universally accurate or accepted description or definition of the informal economy, except that in it activities are insufficiently covered by formal arrangements, leading to workers lacking protection, rights and representation.

1 For instance, in India in 2002, 93 per cent of workers were informal workers. On average, for the year 2000, the levels of informality were 78 per cent in Asia and $5^{2}$ per cent in Latin America. In Africa, where statistics are less reliable and comparable, figures by country indicate high levels of informality too (for example, 8 o per cent for Zambia in 1998) (Bacchetta et al., 2009, 30). 


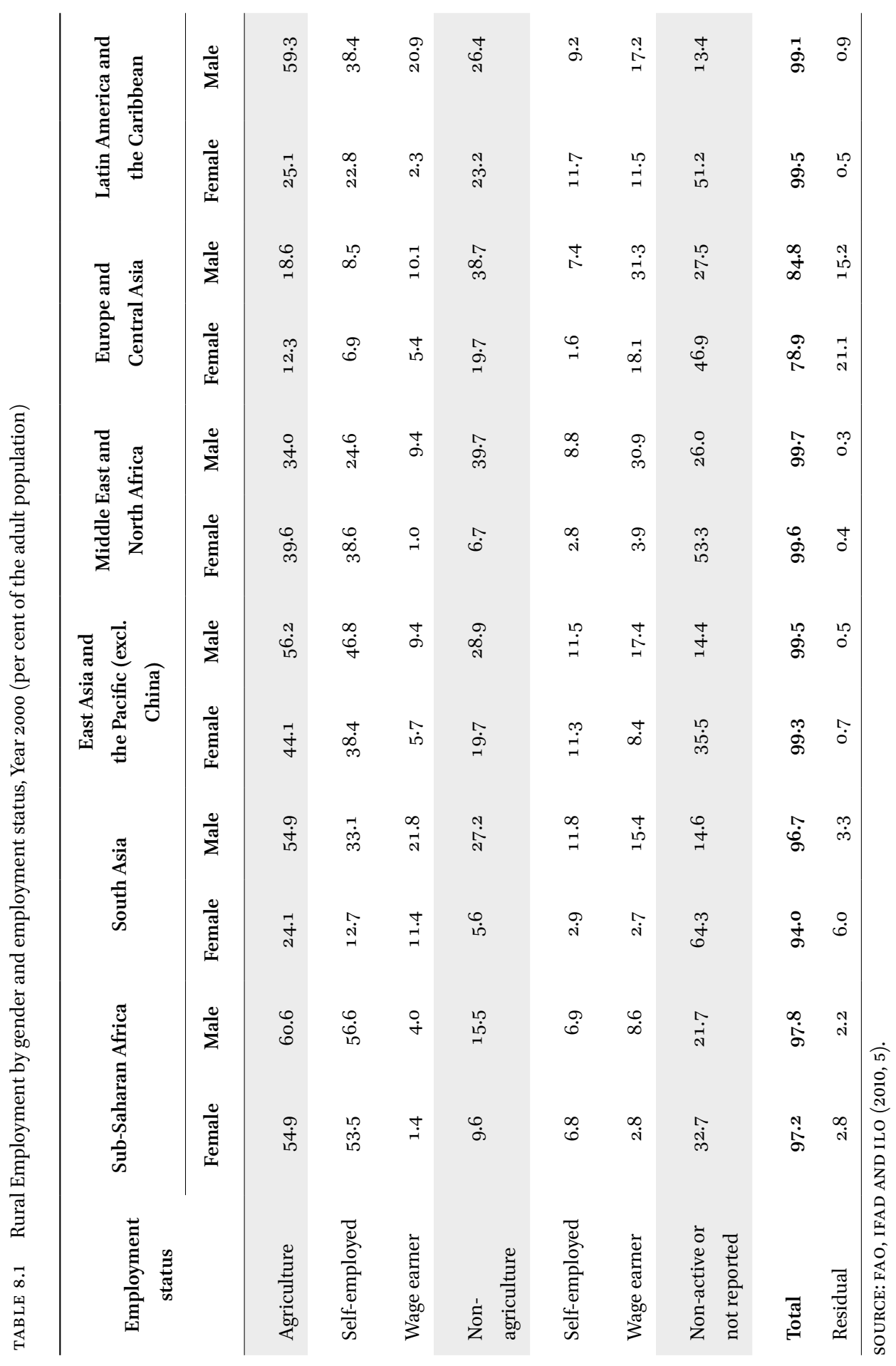


Women are disproportionately affected by informality (ILO, 2016, 11) and are thus considerably disadvantaged. In addition, across the world, unpaid reproductive work - goods, services or care for the household—is mostly performed by women. ${ }^{2}$ This unequal sexual division of work has been recognised as being a persistent source of inequalities, particularly regarding access to the formal labour market. Generally, women are more likely to work shorter hours for pay or profit. Globally, in 2016, women represented less than 40 per cent of total employment and made up 57 per cent of those working on a part-time basis (ILO, 2016, 17). Women's contributions to the global economy thus include a huge amount of work that is either not valued as work and thus not included in Gross National Product (GNP) calculations (UNDP, 1995) or that does not lead to equal benefits, rights, protection and space for political participation.

The ILO's contributions on Third World peasant women's work contributed to the broad recognition of women's work and fuelled the gender and development debate. To better understand these debates and contributions, it is necessary to include a brief discussion on the notion of 'development', and on the construction of the field of knowledge 'gender and development'.

\section{Discussing Development as a Specific Reading of the Trajectories of Societies}

The term 'development' was coined in 1949 in an address by the then newly elected President of the US, Harry Truman, and was linked to a call to fight poverty and hunger:

More than half the people of the world are living in conditions approaching misery. Their food is inadequate, they are victims of disease. Their economic life is primitive and stagnant. Their poverty is a handicap and a threat both to them and to more prosperous areas [...]. What we envisage is a program of development based on the concepts of democratic fair-dealing $[\ldots]$. Greater production is the key to prosperity and peace.

H. TRUMAN, 1949, author's emphasis

Today, 70 years later, half the global population is rural, poverty is persistent and hunger has not been eradicated. Famines repeatedly occur, including in

2 Women spend an average of 4 hours and 30 minutes per day on unpaid reproductive work (ILO, 2016, 20), with important variations due to social belongings (class, race, caste, gender) and across countries. 
1970 in the Sahel region, in 2008 with world food prices at their highest levels, or at the time of writing in Yemen and Sudan. According to its Charter, the UN (1945) has, amongst other aims, the goal to 'promote social progress and better standards of life in larger freedom'. However, 'development' did not eradicate hunger, and famine and food riots are recurrent. Unequal power relations along gender, race and class lines are persistent and inequalities are growing.

Diverse schools of thought have addressed development processes, from 'developmentalists' (Rostow, 1963) and dependence theorists (Frank, 1969; Amin, 1973; Furtado, 1976; Wallerstein, 2006) to 'decolonial' theorists (Quijano, 1992; Escobar, 1988 and 2004). Adherents of the developmentalist current argued that modernisation theories would pave the way for 'underdeveloped' countries to take off in order to catch up with 'developed' countries and that, overall, wealth would trickle down from the rich to the poor. For theorists of dependency the 'periphery' was hampered by unequal trade relationships and needed to sever its dependency ties to the 'centre' in order to industrialise in similar ways. The association of 'development' with a process moving from 'underdeveloped' (and primarily rural) to 'developed' (and industrial) states has reinforced the image of agriculture as a sector of activity that had to be transformed in depth. The contemporary agricultural revolution (Mazoyer, 2002) introduced rapid changes, in the form of large-scale, mechanised, chemicalised, intensified systems of production. Small farming systems were generally considered as 'primitive', poorly 'developed', and 'backward', with low productivity and irrational ways of producing, not related to the global economy. Agricultural industrialisation, meanwhile, was considered a necessary step towards modernity and 'development'. Peasants were seen as a group that would progressively disappear.

A critical analysis of the 'development' discourse suggests that it constitutes a system of beliefs that imposes its specific reading on the trajectory of societies (Quijano, 1992; Rist, 1996). The concept of 'coloniality of power' has interrogated this Euro-American modernist and 'civilising mission' that is considered as a form of intellectual colonialism. Decolonial feminist scholars have significantly contributed to critically revisiting development theories, incorporating gender, class and race exclusions, including marginalised female peasants, and revealing the production-reproduction nexus (Benería, 1979; León, 1982 and 1985; Elson, 1991; Agarwal, 1992 and 1994). Today, the dominant industrialised agricultural system of production is under scrutiny and movements working towards sustainable, healthy and more equitable food-production systems are gaining momentum, including agro-ecological movements, where female farmers and feminist claims are very present. These critical views have contributed to re-conceptualising women's work and suggest that we reflect on how 
this specific reading of the trajectory of societies influences the discussion on formalisation—namely, of women's work — and the debate on unpaid reproductive work, including peasant women's work.

\section{$4 \quad$ Rural Women and the Construction of the Gender and Development Field of Knowledge}

The drive to include women in development has existed ever since the discussion on development began (Verschuur, 2009; Verschuur et al., 2014). As a result of pressures exerted by feminist movements, the UN included consideration of the advancement of women's rights, since its very inception, both in its discourse and in the practices of its institutions. Already in 1946, a Commission on the Status of Women (CSW) was formed within the UN Commission for Human Rights in order to address problems faced specifically by women and to introduce equality between women and men.

Academics too exerted, through their writings, an influence to include women's issues, writings that informed the policies of international institutions and fostered change in conceptual and analytical frameworks. The seminal work, Woman's Role in Economic Development (1970), by Ester Boserup, a Danish economist, provided an analysis of the labour of peasant women in Africa, Asia and Latin America, arguing that both colonialism and modernisation policies had had negative effects on women's status. This analysis, while having several insufficiencies, opened the way to recognition of female farmers and their work. At the time, the term 'gender' had not been coined and power relations, in particular in the family, were not taken into consideration. Inspired by feminist practices, the works of feminist scholars fuelled women's liberation movements, which, in turn, exerted added pressure on the UN and international cooperation organisations. These various pressures led the UN CSW to launch International Women's Year, in Mexico City in 1975. Subsequently, the Commission held the responsibility for the organisation of women's conferences, including in Copenhagen in 1980, Nairobi in 1985 and Beijing in 1995. The ILO contributed importantly to the huge body of research and publications that was produced during this period, as we will see. These moments were particularly important to the creation of a field of knowledge on women/ gender and development and to the push for resolutions, recommendations and plans of action to introduce gender into development institutions, programmes and policies.

In a first moment, the previously unacknowledged work of women, in particular that of Third World peasant women, was recognised as such (Benería and 
Sen, 1981; Boserup, 1970). The next period was marked by analyses of the social relations of sex, race and class within the new international division of labour in the context of globalised neo-liberal capitalism. Many studies focused on issues such as the integration of women into the delocalised manufacturing industry, the feminisation of the proletariat, women's increasing importance in informal urban economies and the feminisation of migration (Verschuur and Catarino, 2013). The ILO was the driver, with domestic workers associations, of the promotion of a groundbreaking resolution on domestic workers (No. 189, in $2011^{3}$ ), and carried out extensive work on migrant women workers and indigenous women. However, female small farmers and rural workers were not part of the main research or policy agendas of the ILO during this period. In the following period, researchers and feminist movements deconstructed the colonial image of the supposedly homogeneous 'Southern woman' and provided an impulse for the re-examination of the interlocking nature of race, caste, class and gender categories, as well as for critiques of the hegemony of Western feminisms (Mohanty, 1988), which had also contributed to the marginalisation of rural women's issues, opening the way for analyses and practices that consider individuals as subjects of their own history (Rauber, 2003). Women's and feminist movements in the global South contributed to the emergence of concepts such as the solidarity economy or the right to food, and of environmental concerns and the defence of alternative systems of production, as networks like Via Campesina $a^{4}$ do, taking into account intersectionality.

Critical theories on 'development', the inclusion of an intersectional and decolonial approach in the women/gender and development field and social, economic, financial and environmental crises have led to a rethinking of the agrarian question and the place and work of marginalised women-whose livelihoods are related to rural areas. These issues have been brought back to the agenda in the ILO.

\section{Ebbs and Flows in the ILO on Rural Development-Women and Work in Agriculture}

Rural development has been on the ILO's agenda since the Organization's establishment in 1919. The 1921 ILC is sometimes referred to as the 'Agricultural

3 See the website https://www.ilo.org/dyn/normlex/en/f?p=NORMLEXPUB:1210o:o::NO: :P1210o_ILO_CODE:C189 (accessed on 13 August 2018).

4 International peasant's movement. For more information, see https://viacampesina.org/en/ (accessed on 8 August 2018). 
Session', since many agriculture-centred conventions and recommendations were adopted (on unemployment, living conditions, night work for women and youths, the right to association). In 1922, it was decided ${ }^{5}$ that the ILO should concern itself with workers in agriculture as well as those in industry, and shortly afterwards the first Director General, Albert Thomas, established an Agricultural Division (de Luca et al., 2011, 13). Since then, the ILo has adopted over 30 international labour standards that are of direct relevance to agriculture and rural development. In the beginning, the main concerns of the ILO in rural areas were labour standards, working conditions, social dialogue and employment issues.

Expert committees were set up on indigenous labour and work on plantations, and rural employment conditions were a priority in the ILO's work. In 1951, stronger relations were established with the Food and Agriculture Organization (FAO), confirming the ILO's mandate to work in rural areas, more specifically on training, cooperative development, rural industries and migration (de Luca et al., 2011, 19). With the decolonisation process starting from the 1950 s, priorities changed from an emphasis on modern industry to rural issues. With the arrival of new member states from 'developing economies', agricultural and rural issues became dominant. Rural issues became central to the ILO's work from the 1950s onward, peaking in the 1970s and 1980s.

The ILO's Resolution $1960^{6}$ highlighted the challenge of rural development and set up an Office-wide, rural-oriented strategy. In 1969, the ILO had launched the World Employment Programme (WEP), and the Director General's report introducing the WEP stressed (among other points) the need to shift investment from capital-intensive to labour-intensive activities, from physical (i.e. machinery) to human capital, and from urban to rural development (ILO, 1969, 68 and 81).

The Rural Employment Policies Research Branch (EMP/RU), set up in 1973, constituted the lead unit and was designated as the 'in-house hub' for rural matters, promoting research on these issues and designing the ILO's rural development strategy. The emergence of rural issues as a priority was further evidenced at the UN World Food Conference in 1974, which called on the UN to place more emphasis on rural development (de Luca et al., 2011, 21).

5 Between 1922 and 1932, the Permanent Court of International Justice, since 1946 the International Court of Justice, issued four advisory opinions related to the International Labour Organization, two on agriculture, one on women's work at night.

6 See the website https://www.ilo.org/public/portugue/region/eurpro/lisbon/pdf/resolucao ilo_1975.pdf (accessed on 13 August 2018). 
The World Employment Conference (WEC) in 1976 called for 'according high priority to the development of rural areas in all its dimensions, from agriculture modernization to development of agro-based industries, including rural crafts, to the provision of physical and social infrastructure, appropriate technology, vocational training, credit facilities and cooperatives [...], special efforts to ensure effective workers' participation, and agrarian reform including land distribution, to achieve effective national development strategies' (de Luca et al., 2011, 22). However, women in rural areas appeared only sporadically, in chapters referring to disadvantaged groups such as indigenous and tribal people, youth and disabled persons.

\subsection{Innovative Approaches and Debates}

Considerable and high-quality research and analysis was produced during those years by world-renowned scholars (Jolly, 1976; Sen, 1981; Benería, 1982) and on issues of land reform, rural technology and female rural workers, contributing to important innovative concepts. Among these was the 'basic needs' approach (Jolly, 1976; Ghai et al., 1980), the debates on informality, the questioning of growth in itself as a way of ensuring employment creation and poverty reduction or, concerning gender issues, the deconstruction of the concept of women's work and the sexual division of labour (de Luca et al., 2011, 31). A lot of research was also produced on rural cooperatives. This progressive and groundbreaking research provoked resistance, from the constituent parts of and internally within the ILO. Interestingly, the huge volume of research documents and training material produced on cooperatives by Асорам (Appui Coopératif au Programme Alimentaire Mondial-Cooperative and Organizational Support to Grassroots Initiatives) was not supported by the ILO-despite growing prestige within the ILO, important contributions to poverty alleviation by increasing rural employment and securing social rights, and being considered as 'exemplary in gradually strengthening a project's gender sensitivity and in screening projects for gender sensitization' (de Luca et al., 2011, 66). In part, this reluctance is attributed to the fact that 'all documents and training materials were in French' (de Luca et al., 2011, 66), which also tells us a lot about the 'unequal traveling and translation of feminist practices, theories and texts, and their reception' (de Lima Costa and Alvarez, 2014, 558). The rich body of feminist literature produced by non-Anglo-Saxon feminist scholars since the seventies (Delphy, 1970; León, 1982; Bisilliat, 1985; Lagarde, 1994; Devreux, 1995) has been poorly incorporated into the UN apparatus and only weakly influenced debates, programmes or research. Transnational encounters have, however, opened spaces of circulation of ideas. 
In preparation of the first UN conference on women, in Mexico in 1975, a Women's Programme had been opened around the WEP in 1974, with studies on the sexual division of labour and on the contribution of women to development and the gender biases. The $1976 \mathrm{WEC}$ had pointed to the fact that women faced the most disadvantages and had called for action to relieve 'the work burden and drudgery of rural women by improving their living and working conditions and providing more resources for investment in favour of women in rural areas' (Ghai, 1982, vi). The Programme attempted to implement the relevant recommendations of the WEC as well as those adopted by the World Conferences on Women held in Mexico City and Copenhagen in 1975 and 1980 , respectively. The introduction of a seminal book produced by the ILO on women and development recognised that the studies published in the book contributed to understanding 'the forces that perpetuate [women's] subordination' (Ghai, 1982, vi).

\subsection{The Programme on Rural Women}

The Programme on Rural Women established in these years was an icebreaker in the UN system. 'I remember how the first reaction of my colleagues [of WEP, where we were initially only two women] to my proposal to calculate women's unpaid work was initially quite negative and received with smiles' (interview with Lourdes Benería, August 2017). The Programme undertook groundbreaking research (Benería, 1982; ILO, 1991b), produced innovative concepts and approaches, 'from women awareness raising, social mobilisation and working collectively to solve problems, generate income, and give women a voice; to increasing women's access to government officials, and awareness-raising among employers to women's needs (in terms of health, education, shelter, water and sanitation); to women capacity building; to micro-finance for income-poor women' (de Luca et al., 2011, 40). 'By 1990, the ILo's analytical work and practical experience had been synthesized in over 150 working papers, books and conference papers covering a wide range of topics' (de Luca et al., 2011, 43).

Research produced by the Programme on Rural Women contributed to discussions not only of what women's work-including domestic work-is, but also of what is considered to be women's work in terms of non-domestic production (Benería, 1982, xiv). It documented how some rural women perform the same agricultural tasks as men, and others perform sex-typed activities like processing food for sale (the Hausa region in Nigeria) or making laces (India). It showed that the sexual division of work in agriculture is not universalcoffee production may be carried out by women or by men according to country, ethnicity, etc.- -and is subject to change according to global economic changes and the process of accumulation. It illustrated the differences between women 
and men in the proletarianisation of the labour force with the transformation of agrarian structures and in the processes of land commercialisation and concentration that occurred in these years. It also illustrated how global economic changes intensified reproduction activities, and how the household also is subject to changes. The Programme on Rural Women not only paid attention to women, it also defended the idea that 'one of the dimensions of women's oppression is the existence of mechanisms of exploitation that feed on and accentuate inequalities related to class and gender' (Benería, 1982, xvi). This accent on the need to link gender and class differences leads us to 'ask questions about the reasons for their existence and about the possibility of doing away with them' (Benería, 1982, xvii). Institutional questions derived from these statements. 'If private ownership, unequal distribution of resources, and a capitalist organization of production result in fundamental class differences-affecting women in a variety of ways - we need to ask whether any institutional change addressed to altering these factors will do away with gender-related mechanisms of subordination affecting women' (Benería, 1982, xvii). Studies showed that a more egalitarian distribution of economic resources was not sufficient and that patriarchal systems need to be challenged in order to achieve real changes with regard to gender equality. Finally, the Programme's remarkable contribution was to document the 'extent to which women's economic activities are underestimated in labour force and national income statistics and are undervalued in general' (Benería, 1982, xvii), including in economic activities other than domestic work. This led to major theoretical contributions to feminist studies, to 'redefine the concept of economic activity, so that it includes not only tasks related to commodity production but also tasks that contribute to human welfare' (Benería, 1982, xvii). The focus on commodity production—in other words, the production of exchange values rather than use values-has distorted the way participation in the labour force is defined. Feminist scholars in the ILO's Programme on Rural Women argued that participation in the labour force should also include use value production (Benería, 1982, xvii). While some efforts had been made to estimate this participation in subsistence agriculture - this was not done in domestic activities, viewed at that time as outside the economic realm - they remained seriously insufficient and often failed to relate it to human welfare rather than to a process of growth and accumulation.

The Programme on Rural Women also supported income-generating projects and grass-roots level organisations and cooperatives among poor rural women. It helped organise women into rural worker's organisations, for instance with the Self-Employed Women's Association (SEWA) in India, ${ }^{7}$ and in

7 For more information, see the website http://www.sewa.org (accessed on 8 August 2018). 
some countries worked with women plantation workers (including in Bangladesh). But although it had contributed to a huge body of knowledge, the Programme had not managed to change the approaches and projects. Projects targeted women, but due to the fact that they did not sufficiently recognise women's already huge burden of work in domestic activities and in subsistence production ended up overburdening the most disadvantaged women. The Programme could not structurally change the mechanisms that reproduce unequal power relations and sexual division of labour; nor could it change the global economic system. It did not get the necessary high-level support to integrate its findings into all the departments of the ILO and remained isolated and poorly funded. For instance, one of the major components of the ILO's rural work in the 1970 os and 1980s, the Special Public Works Programme, had absolutely no mention or inclusion of women or gender issues. The same happened with the ILO Unit Management Development Programme, which focused on small-scale enterprises considered as having an important capacity to 'create jobs, multiply, and satisfy the basic needs of local population' (de Luca et al., 2011, 68). In the ILO programmes also reaching rural areas like Skills, or Occupational Safety and Health and Working Conditions, the absence of gender was also striking.

Tensions also came to surface between concepts and approaches such as 'landlessness, poverty, work at village level, and "traditional" ILO work' (de Luca et al., 2011, 29), or between 'constituents and traditional ILO officials' on the one hand, and the 'donor-funded rural research programme that focused on land reform, organizing the poor and women on the other' (de Luca et al., 2011, 29). In 1987, the EMP/RU, the 'in-house hub' for rural matters, was dismantled. Many innovative approaches and programmes had not been integrated into the ILO, in particular those regarding rural women.

After a marked decline within the ILO for around twenty years, rural issues regained attention from the year 2008 onwards, when hunger riots exploded, illustrating the limits of the agricultural and food production and exchange system, the social, economic, financial and environmental crises and more generally the crisis of social reproduction and the widespread and persistent poverty in rural areas.

The accent on reducing poverty expressed in the international agenda urged the ILO to redirect policies towards rural areas that had been present at the beginning of the ILO's mandate and work. Following its discussion of the ILO (2008) ILO report Rural Employment for Poverty Reduction, the ILC confirmed the need to engage more decisively and urgently in rural areas, mobilising the Decent Work Agenda. The ILC adopted, in 2009, a Resolution and Conclusions to promote rural employment, and a Resolution to put gender equality at the 
heart of decent work. 'In March 2011, the Governing Body adopted a strategy on promoting decent work for rural development, identified as one of the areas for priority action in 2014-15 and one of ten Policy Outcomes in 2016-17 to continue providing high-value services to the ILO's tripartite constituents' (ILO, 2017). In 2011, FAO published its annual report on women in agriculture, recognising their central role as food producers in farming systems; and 2014 was decreed as the year of 'family farming', and joint programmes between the ILO, the International Fund for Agricultural Development (IFAD) and FAO have been established. The 2030 Agenda for Sustainable Development also included priorities on rural development and agriculture and food security.

The concerns of the ILO in rural areas are nowadays related to the Organization's agenda on decent work. As a study on the ILO's rural work legacy observed: 'decent work deficits are numerous and include higher rates of un- and under-employment (especially among youth and women); an alarming prevalence of child labour (agriculture alone represents 60 per cent of all child labour); a high frequency of precarious work as wage workers are mostly temporary or casual; widespread informal activities; limited social protection; exposure to adverse working conditions due to poor labour standards coverage and monitoring; and little or no unionization' (de Luca et al., 2011, 13). The Decent Work Agenda in rural areas includes, according to ILO statements, paying 'special attention to women, youth, and other disadvantaged groups with untapped potential' (de Luca et al., 2011, 16). It addresses 'issues such as access to skills and employment services, sustainable entrepreneurship, extension of social protection and improved occupational safety and health and working conditions, International Labour Standards, and the need for strengthened rural organization' (de Luca et al., 2011, 16).

Agriculture is acknowledged as being the main source of rural employment for both women and men in sub-Saharan Africa, South Asia and South-East Asia. In Latin America, female rural work is equally distributed between agricultural and non-agricultural sectors. In the Middle East and North Africa, rural women work mostly in agriculture and rural men as non-agricultural wage earners. In Central Asia and Europe, the majority of the rural population works as waged employees in non-agricultural activities (FAO, IFAD and ILO, 2010, 4). In all cases, a significant proportion of women are either 'self-employed', as referred to by the FAO, IFAD and ILO report, or non-active or 'not-reported'. Decent rural work programmes by the ILO concentrate however on 'remunerative 
employment' (FAO, IFAD and ILO, 2010, 20), where women are only marginally represented. Unpaid work and informal work are not part of the Decent Work Agenda. As underlined by a high-level officer: '[The] ILO's specific area of work is wage-workers' (personal interview with van Leur, Director of the Sectoral Policies Department, July 2017).

While the Decent Work Agenda does mention the necessity to '[take] women's role in the care economy adequately into account, for instance through work-family balance measures and providing workplace-level incentives for the provision of childcare and parental leave' (ILO, 2018), this concerns only formal workers. Unpaid and reproductive work-including food production, goods, services and care- carried out by women in rural economies, in particular in agriculture, is thus still not taken into account in the Decent Work Agenda and does not give access to women, as workers, to rights, social protection and representation.

The ILO's tripartite structure enables employers' organisations and trade unions to be officially represented in its governing bodies. However, feminist scholars and movements question to what extent mainstream trade unionsgenerally male dominated-represent the specific interests of women workers. More importantly, and specifically in rural areas since women constitute a major proportion of unorganised workers and unpaid agricultural workers (see Table 8.1), there is a serious shortcoming with regard to voicing rural, less advantaged women's interests. At the level of governments, while a small number of them are strong promoters of gender equality (for instance the Nordic countries, Australia, Canada and the Netherlands), many others do not include gender equality as a real priority, even if gender mainstreaming is present in the discourses. Rural agro-industrial lobbies may also have decisive power to influence their governments and the employers' parties so that support towards small peasants is reduced. All of this reinforces the marginalisation of a major proportion of women in agriculture.

Working on rural economies implies coordination and collaboration but also some tensions and competition with other specialised agencies of the UN that have a specific mandate to deal with agriculture and food issues (in particular FAO and IFAD). The ILO explained its focus on decent work for wage-earners in rural economies in order to define its specificity. In 2010, FAO, IFAD and the ILO prepared a joint report on gender and rural employment, based on an impressive number of studies and research from different agencies and scholars. It extends the notion of women's participation in rural employment to 'farming, self-employment working in trade, small enterprises providing goods and services, wage labour in these and wage labour in agriculture' (FAO, IFAD and ILO, 2010, 3). The report describes the gendered constraints that women 
in rural economies face and how to reduce them. In 2012, the ILO, FAO and IFAD jointly organised a panel discussion, during the 56 th Session of the Csw, on Rural Employment and Agriculture. Amongst other issues, 'examples and success stories of cooperatives unleashing rural women's potential and giving them a stronger voice' were presented (ILO, 2012, 2). Recognition of women as farmers with associated rights was included in the issues discussed, as was 'decent work for indigenous women in rural areas' (ILO, 2012, 2). ILO Convention No. 169 on Indigenous and Tribal Peoples ${ }^{8}$ was highlighted as a framework for indigenous women's rights.

The ILO's Sectoral Unit on the Rural Economy ${ }^{9}$ has prepared, since its establishment in 2013, a series of policy guidelines on gender and rural issues, one of which focuses on women's empowerment. On International Women's Day 2012, the chosen focus was to 'empower rural women-end hunger and poverty', and a call was made to increase employment, education and organisation as key tools in the empowerment of rural women. There seems to be a shift from the category gender-sometimes understood as a politically correct concept that displaces attention to men - to women's empowerment and continuous attention to women's grass-root level initiatives and 'small projects' (personal interview with van Leur, Director of the Sectoral Policies Department, July 2017).

The ILO considers that 'the rural economy holds significant potential for creating decent and productive jobs and contributing to sustainable development and economic growth' (ILO, 2017). The lack of support given to rural areas is considered by an ILO report as 'missed opportunities', 'such as the waste of agricultural produce $[\ldots]$; an under-utilization of the rural workforce $[. .$.$] . Well-$ developed rural areas hold considerable potential for economic growth with high returns and good, productive jobs and livelihoods' (de Luca et al., 2011, 13). Rural areas are seen as having a potential that needs to be unlocked, and investing in them is seen as 'good business' (de Luca et al., 2011, 14). Supporting rural areas is understood as being 'smart economics', following the World Bank in its proposal to invest in women and girls and in women's empowerment as individual persons, to reinforce the efficiency of the neo-liberal economic model of development. However this 'smart economics' approach has been widely criticised by feminist scholars as one that is embedded in the neo-liberal gender agenda, aiming at investing in women and girls for more efficient

8 See the website https://www.ilo.org/dyn/normlex/fr/f?p=1000:12100:0::NO::P1210o_INSTRUMENT_ID,P1210o_LANG_CODE:312314,en:NO (accessed on 13 August 2018).

9 Forestry, Agriculture, Construction and Tourism (FACT) Unit of the Sectoral Policies Department (SECTOR). 
development outcomes (Chant, 2012). This instrumental approach considers women as an underutilised resource, it does not understand the concept of gender as an expression of power (Scott, 1986), it does not take into account the critical approaches to empowerment, the analysis of women's subordination and of the mechanisms that reproduce gender and social inequalities. $\mathrm{Nu}-$ merous studies have demonstrated that the neo-liberal model of development cannot contribute to increase social and gender justice and to reduce inequalities, poverty and hunger without structural changes (Razavi, 2002 and 2009; UNRISD, 2005). The way the Decent Work Agenda is conceptualised could benefit from critical feminist analysis on 'smart economics', from the seminal contributions the ILO's Programme on Rural Women has made on social reproduction, and from the critical analysis of the specific reading of the trajectories of societies offered by 'development' and feminist studies. Some of this has indeed been included in the programme of the ILO's Bureau for Gender Equality. Besides many resolutions ${ }^{10}$ that respond to long lasting feminist struggles, important efforts have been made to encourage the recognition, redistribution and reduction of care work, considered as the cause of the reproduction of gender inequalities, in particular in relation to access to employment.

Women's Work in Agriculture, Social Reproduction, and Family Agriculture

Research on agricultural activities has for a long time neglected small-scale family farming, associated with backwardness and unproductivity, and irrationality — a system of production that was considered unable to feed the world. Women in agriculture have often only been represented as spouses or daughters, not as workers. The female small peasant's work has long been considered as 'help' and not as work. Failure to acknowledge the power relations and the division of work in the household and the farm has tended to reinforce inequalities and devaluate the specific knowledge, practices, and crops cultivated by women peasants. It has also meant ignoring issues of unequal rights to land, to means of production, to the market, and of unequal participation

10 The Equal Remuneration Convention (No. 100); the Discrimination in Employment and Occupation Convention (No. 111); the Workers with Family Responsibilities Convention (No. 156); the Maternity Protection Convention (No. 183); the Resolution concerning Gender Equality at the Heart of Decent Work; the Resolution concerning the Promotion of Gender Equality, Pay Equity and Maternity Protection; and the Convention for Domestic Workers (No. 189). See the website https://www.ilo.org/gender/Aboutus/ILOandGenderEquality/lang--en/index.htm (accessed on 13 August 2018). 
in decisions regarding the process of production and distribution. The underrepresentation of women in rural unions and farmers' unions contributes to their invisibility, notably that of their agency, and disregards their political subjectivity.

Feminist and critical rural social scientists have highlighted instead the centrality of the small peasantry in food production and the importance of women's work, as peasants as well as wage earners. They have shown how the sexual division of work, with marginalised peasant women working on subsistence production and men as wage earners, sustains the prosperity of the global economy. As an ILO publication of 1993 noted, "[agricultural] workers are not fully salaried and depend for a part of their income on the produce of their small farms, most often in the hands of women. This subordination of small peasant production to the labor market allows employers to pay a very low daily wage to agricultural workers' (Egger, 1993, 58, author's translation). These words from an ILO official illustrate well the articulation between different systems and relations of production, which is pivotal for the working of the global economy (Meillassoux and Verschuur, 1985).

Social reproduction includes all activities, relations and institutions that are necessary for the reproduction of life. It comprises biological reproduction, the reproduction of the labour force, and all activities that are necessary for daily life and future generations. This includes, for instance, food production, preparation and transformation, petty commodity production and commercialisation, caring for the others (dependents and non-dependents) and caring for nature. Unpaid labour in the production of goods and services and in care is considered a fundamental economic activity in feminist economics.

With changes in systems of production, changes related to globalisation and male migration, the marginalisation and workloads of rural women often increased, due to the persistent unequal sexual division of labour in agriculture and to unequal access to the workforce, agricultural inputs, technologies, credit and land. One of the major constraints faced by women peasants and agricultural wage earners is the continuous and increasing nature of reproductive work, which relies disproportionately on the most excluded women because of unequal power relations, sexual division of labour in the family and the coloniality of power. With neo-liberal globalisation, a crisis of social reproduction can be observed (Federici, 1999) and includes disappearing public services, unemployment and falling wages. In rural areas, the reproductive activities of disadvantaged women peasants are particularly burdensome due to poor infrastructure (electricity, water, roads...) and a lack of facilities and institutional support (day care, schools, health centres, social protection schemes...). 
The food crisis and the crisis of social reproduction have generated doubts about the sustainability of the agribusiness model, for social, economic and environmental reasons. This has led to the rehabilitation of and support for other systems of production that value food production, agro-ecological practices and support for family agriculture. This change of perspective is not only due to the food crisis, it is also a consequence of the mobilisation of rural social movements claiming the right to land and to decent work and livelihoods, and of ecological movements. Family agriculture has featured in development agencies (FAO decreed 2014 to be the year of family agriculture) and public policies as a strategic proposal to fight poverty and improve food security through the modernisation of agriculture.

Public policies with regard to family agriculture are promoting enhanced productivity and farmers' participation in the market, mainly through access to credit provided to the most integrated 'productive farmers'. These policies mainly aim at an increased integration of the farmer into the capitalist system and not at the construction of alternative models of production and alternative markets, nor at pushing forward agrarian reform agendas or including feminist issues. While such moves seem to be an attempt to create a new social identity to replace the traditional opposition between large- and small-scale agriculture, they still lack a clear definition and do not provide an analysis of the system of production, on the scale of the land, on the sexual division of work, on the gender inequalities in the family, or on the nature of work, and of marginalised women's work in particular.

Some social movements, including Via Campesina mentioned above, contest the very category of family agriculture as not being representative of the peasants and their values and not in line with their struggles for change. Other rural social movements have envisaged family agriculture as the construction of alternative modes of agricultural development, to defend small-scale peasants and peasants without land (much like in Brazil, with the Movimento Sem Terra $[\mathrm{MST}]^{11}$ ), decent work and livelihoods and sound environmental practices. Women's movements, including the Marcha das Margaridas ${ }^{12}$ in Brazil, included feminist issues in their claims, including women's equal access to land titles and to social rights as workers, extension services directed at female farmers, the struggle against gender violence, and women's political representation.

11 For more information, see the website http://www.mstbrazil.org/content/what-mst (accessed on 8 August 2018).

12 For more information, see the website http://transformatoriomargaridas.org.br/?page id=139 (accessed on 13 August 2018). 
Data are difficult to obtain on female agricultural-waged workers since it is a complex category, including irregular, part-time, seasonal, unregistered and non-formal work and data collection is scarce. Women are generally far less often employed as rural wage earners than are men (see Table 8.1 above). FAo's report on the State of Food and Agriculture 2010-11, which focused for the first time on women and agriculture, provides some scattered information on the employment gap between men and women (FAO, 2011). For instance, 'almost 15 per cent of men but fewer than 4 per cent of women are employed for wages in Ghana. The gap is even wider in some other countries, such as Bangladesh, where 24 per cent of rural men and only 3 per cent of rural women work in wage employment. [...] In Ecuador almost 30 per cent of rural men and only 9 per cent of rural women receive a wage' (FAO, 2011, 18-19). However, women constitute the majority in several export-oriented agro-industries, including for instance in Colombia's flower industries. In all cases, women 'are more likely to be in part-time, seasonal and/or low-paying jobs. Similarly, rural wageearning women are more likely than men to hold low-wage jobs' (FAO, 2011, 19). More data and analysis with regard to female agricultural workers is needed.

\section{8} Conclusion

The ILO's Decent Work Agenda in rural areas concentrates on rural wage earners. However, this means neglecting the majority of women in rural areas, who do not work mainly for wages or profit. If the Decent Work Agenda is about promoting social and gender justice, it needs to be extended to all women, including both small peasants who are working to provide a livelihood for their families, rural waged workers and the urban poor. It needs to be better informed by previous debates in the ILO, which contributed to the recognition of the place of women in social reproduction in a broad sense, including care and also producing food, goods and services and livelihood provision for all. This work is mostly performed by marginalised women in the form of unpaid, non-registered or informal work.

Women have long been associated either with the domestic sphere or with subsistence farming, which has contributed to them being ignored and devalued as workers and their central contribution to food security and social reproduction has been disregarded (Boserup, 1970; Benería, 1982; FAO, 2011). Until today, peasant women still lack equal access to recognised status as farmers, to policies and resources that support agricultural production and to social rights and social protection, and lack a voice and representation in rural trade unions. 
The attention given to women and development issues was born from research on rural women carried out in the 1970s. Their work, their knowledge, their place in agricultural systems of production and their central role in livelihoods and social reproduction was late to be recognised and this led to changes in women's influence in development policies, programmes and research programmes. With the organisation of the United Nations World Conferences on Women, which connected feminist movements and scholars and stimulated research and evaluation programmes, a large field of study on women/gender and development has been constituted. Feminist studies and women's movements discussed and challenged the sexual division of labour and asked 'difficult questions about how societies are organized to satisfy basic human needs' (Benería, $1982, x i)$, and women's struggles for equality posed 'fundamental questions about the nature of inequality, of exploitation and subordination, and about the type of social change necessary to eliminate them' (Benería, 1982, xi).

Feminist studies introduced the concept of gender as an expression of power (Scott, 1986). Women's oppression is not only located in the labour market and in the sphere of paid production, seen as essentially outside the domestic sphere. It is also located in the family - the home of unpaid domestic work and food production. Thus attention needs to be paid also to unequal power relations in the household, to the patriarchal system that influences all socialising institutions - that lead to women's subordinate position in the paid labour market - to the sphere of reproduction and to the articulation between production and reproduction. The struggle against women's oppression thus needs not only equality of access to the sphere of non-domestic production (paid and unpaid) but also transformations of unequal power relations and of the unequal division of reproductive activities in the household.

Groundbreaking research on gender equality issues took place at the ILO in the 1980 s and brought with it solid, innovative feminist labour economics contributions. The ILO established a Gender Equality Policy in 1999. Following the 1995 Beijing Plan of Action and the dissemination of gender mainstreaming policies, the number of staff working on gender issues significantly increased, gender was integrated into the ILO's technical co-operation programmes, gender guidelines were elaborated and gender training was given — much targeted specifically at women - and the systematic inclusion of women in all projects was encouraged. In that respect, the ILO is one of the UN organisations that has integrated gender equality issues most significantly.

As in most international agencies, gender has become a priority but is often still not adequately budgeted for. Gender experts lack power and legitimacy and strategies to deploy gender in the institution are subject to political changes. The ILo Bureau for Gender Equality (now called the Gender, Equality and Diversity Branch) has not always benefitted from the same well-placed 
institutional position and resources with which to influence policy. It lacks the power to influence some departments and sectorial approaches. Through its Gender Network, the Gender, Equality and Diversity Branch at the ILO recently highlighted a number of areas in which stronger efforts need to be made to support constituents. These include recognising domestic work as work, violence and sexual harassment in the workplace, improving equal pay for work of equal value, and ensuring that the Decent Work Agenda and gender equality maintain their relevance on international and national agendas during times of crisis, and continue to influence the high-level policy forums of intergovernmental organisations and the UN (ILO, 2012, 3).

While gender mainstreaming has grown appreciably at the ILO and gender is supposedly at the top of the Organization's list of priorities, the theoretical feminist contributions made by the ILO in the 1980s, which deconstructed what work is and in particular what female peasants' work is, have remained difficult to introduce into programmes and policies. Whereas rural employment and the rural economy have once again returned as one of the priorities of the ILO, after a marked decline, gender, rural issues and the Decent Work Agenda combined could benefit more from the previous research and theoretical contributions of the ILO, and from the burgeoning, organised social movements of peasant women, who contest the dominant agricultural model, trade unions and lobbies. Recognising, reducing and redistributing care (Fraser, 2004) as one of the levers with which to reduce gender inequalities is now part of the ILO's and the Sustainable Development Goals (SDGs) agenda. While this is a big achievement, there is a need for a broader vision on rural women and social reproduction in the Decent Work Agenda.

\section{Acknowledgements}

I would like to thank immensely Lourdes Benería, Emeritus Professor at Cornell University, for her comments and helpful contributions to this chapter.

The title of this chapter is inspired by a book by bell hooks (1984) Feminist Theory: From Margin to Center (Cambridge, MA: South End Press).

\section{References}

Agarwal, B. (1994) A field of one's own: Gender and land rights in South Asia (Cambridge: Cambridge University Press).

Agarwal, B. (1992) 'The Gender and Environment Debate: Lessons from India', Feminist Studies, 18(1), pp. 119-158, https://www.jstor.org/stable/3178217. 
Amin, S. (1973) Le développement inégal (Paris: Ed. de Minuit).

Bacchetta, M., E. Ekkehard and J.P. Bustamante (2009) Mondialisation et emploi informel dans les pays en développement (Geneva: WTO and ILO).

Benería, L. (1982) Women and development; the sexual division of labor in rural societies. A study prepared for the International Labour Office within the framework of the World Employment Programme (New York: Praeger Publisher).

Benería, L. (1979) 'Reproduction, production and the sexual division of labour', Cambridge Journal of Economics, 3(3), pp. 203-225

Benería, L. and G. Sen (1981) 'Accumulation, Reproduction, and "Women's Role in Economic Development”: Boserup Revisited', Signs: Journal of Women in Culture and Society, 7(2), pp. 279-298, https://www.jstor.org/stable/3173878.

Bisilliat, J. (1985) 'Synthèse des travaux (à partir des débats)', in J. Bisilliat and G. Courade (eds.) Femmes et politiques alimentaires. Actes du séminaire international sur la place des femmes dans l'autosuffisance (Paris: Éditions de l'ORSTOM), pp. 23-33.

Boserup, E. (1970) Woman's Role in Economic Development (London: George Allen \& Unwin).

Chant, S. (2012) 'The disappearing of "smart economics"? The World Development Report 2012 on Gender Equality: Some concerns about the preparatory process and the prospects for paradigm change', Global Social Policy, 12(2), pp. 198-218, DOI: $10.1177 / 1468018112443674$.

Delphy, C. (1970) 'L'ennemi principal', Partisans, $n^{\circ}$ spécial Libération des Femmes, 5455, July-August, pp. 57-172.

Devreux, A.M. (1995) 'Sociologie "généraliste" et sociologie féministe: les rapports sociaux de sexe dans le champ professionnel de la sociologie', Nouvelles questions féministes, pp. 83-110, https://www.jstor.org/stable/40620033.

Egger, P. (1993) Travail et agriculture dans le Tiers Monde. Pour une politique active de l'emploi rural (Geneva: ILO).

Elson, D. (1991) Male Bias in the Development Process (Manchester and New York: Manchester University Press).

Escobar, A. (2004) 'Beyond the Third World: imperial globality, global coloniality and anti-globalisation social movements', Third World Quarterly, 25(1), pp. 207-230, https://www.jstor.org/stable/3993785.

Escobar, A. (1988) 'Power and visibility: Development and the invention and management of the Third World', Cultural Anthropology, 3(4), pp. 428-443, https://www .jstor.org/stable $/ 656487$.

FAO (Food and Agriculture Organization) (2011) La situation mondiale de l'alimentation et de l'agriculture. Le rôle des femmes dans l'agriculture. Combler le fossé entre les hommes et les femmes pour soutenir le développement (Rome: FAO).

FAO, IFAD (International Fund for Agricultural Development) and ILO (International Labour Organization) (2010) Gender dimensions of agricultural and rural 
employment: differentiated pathways out of poverty. Status, trends and gaps (Rome: FAO, IFAD and ILO).

Federici, S. (1999 [2002]) 'Reproduction et lutte féministe dans la nouvelle distribution internationale du travail', in C. Verschuur and F. Reysoo (eds.) Genre, mondialisation et pauvreté (Geneva and Paris: L'Harmattan), pp. 45-69.

Frank, A.G. (1969) Le développement du sous-développement (Paris: François Maspéro).

Fraser, N. (2004) 'Justice sociale, redistribution et reconnaissance', Revue du MAUSS, 1(23), pp. 152-164, DOI: 10.3917/rdm.023.0152.

Furtado, C. (1976) Le mythe du développement économique (Paris: Ed. Anthropos).

Ghai, D. (1982) 'Introduction', in L. Benería (ed.) Women and development; the sexual division of labor in rural societies. A study prepared for the International Labour Office within the framework of the World Employment Programme (New York: Praeger Publisher).

Ghai, D., A. Rahman Khan, E. Lee and T. Alfthan (1980) The basic-needs approach to development. Some issues regarding concepts and methodology (Geneva: ILO).

hooks, bell (1984) Feminist Theory: From Margin to Center (Cambridge, MA: South End Press).

ILO (International Labour Organization) (2018) Gender, Equality and Diversity Branch, https://www.ilo.org/gender/lang--en/index.htm (accessed on 21 February 2018).

ILO (2017) Decent work in the rural economy, Governing Body, 329th Session, Geneva, 9-24 March 2017, https://www.ilo.org/wcmsp5/groups/public/---ed_norm/--relconf/documents/meetingdocument/wcms_545617.pdf (accessed on 1 June 2017).

ILO (2016) Women at Work. Trends 2016 (Geneva: ILO), https://www.ilo.org/wcms p5/groups/public/---dgreports/---dcomm/---publ/documents/publication/ wcms_457317.pdf (accessed on 13 August 2018).

ILO (2012) ILO Gender News (Geneva: ILO), https://www.ilo.org/gender/lang--en/ index.htm (accessed on 13 August 2018).

ILO (2009) Women's Empowerment. go Years of ILO Action (Geneva: ILO), https://www .ilo.org/wcmsp5/groups/public/@dgreports/@gender/documents/publication/ wcms_105088.pdf (accessed on 13 August 2018).

ILO (2008) Promotion of Rural Employment for Poverty Reduction, Report IV, International Labour Conference, 97th Session (Geneva: ILO), https://www.ilo.org/ wcmsp5/groups/public/---ed_norm/---relconf/documents/meetingdocument/ wcms_091721.pdf (accessed on 13 August 2018).

ILO (1991a) The dilemma of the informal sector. Report of the Director-General to the International Labour Conference, 78th session (Geneva: ILO), https://www.ilo.org/ wcmsp5/groups/public/---ed_norm/---relconf/documents/meetingdocument/ wcms_218128.pdf (accessed on 13 August 2018).

ILO (1991b) Rural Development: An Annotated Bibliography of ILO Publications and Documents. 1983-199o (Geneva: ILO), http://agris.fao.org/agris-search/search. do? recordID=XF2016059173 (accessed on 13 August 2018). 
ILO (1969) The World Employment Programme (Geneva: ILO), https://www.ilo.org/ public/libdoc/ilo/P/og605/09605(1969-53-part-1).pdf (accessed on 13 August 2018).

Jolly, R. (1976) 'The world employment conference: the enthronement of basic needs', Development Policy Review, 9, pp. 31-44, DOI: 10.1111/j.1467-7679.1976.tboo338.x.

Lagarde, M. (1994) 'Perspectiva de género', Diakonia, 71, pp. 23-29.

León, M. (1985) 'La Medición del Trabajo Femenino en América Latina: Problemas Teóricos y Metodológicos', in E. Bonilla (ed.) Mujer y Familia en Colombia (Bogotá: Plaza and Janes Editores), pp. 205-222.

León, M. (1982) Las Trabajadoras del Agro (Bogotá: ACEP).

de Lima Costa, C. and S.E. Alvarez (2014) 'Dislocating the Sign: Toward a Translocal Feminist Politics of Translation', Signs: Journal of Women in Culture and Society, 39(3), pp. 557-563, DOI: 10.1086/674381.

de Luca, L., M. Fernando, E. Crunel and L.O. Smith (2011) Unleashing The Potential For Rural Development Through Decent Work Building on the ILO Rural Work Legacy 1970-2010 (Geneva: ILO).

Maruani, M. and M. Meron (2013) 'Le travail des femmes dans la France du XX ${ }^{\mathrm{e}}$ siècle', Regards croisés sur l'économie, 1(13), pp. 177-193, DOI: 10.3917/rce.013.0177.

Mazoyer, M. (2002) Une situation agricole mondiale insoutenable, ses causes et les moyens d'y remédier, Mondes en développement, 1(117), pp. 25-37, DOI: 10.3917/ med.117.0025.

Meillassoux, C. (1975) Femmes, greniers et capitaux (Paris: François Maspéro).

Meillassoux, C. and C. Verschuur (1985) 'Les paysans ignorés du Mozambique', Le Monde diplomatique, October, https://www.monde-diplomatique.fr/1985/10/MEIL LASSOUX/38840 (accessed on 9 August 2018).

Mohanty, C.T. (1988) 'Sous les yeux de l'Occident. Recherches féministes et discours coloniaux', in C. Verschuur (ed.) Genre, postcolonialisme et diversité des mouvements de femmes (Paris: L'Harmattan), pp. 171-202.

Quijano, A. (1992) 'Colonialidad y modernidad/racionalidad', Perú indígena, 13(29), pp. 11-20.

Rauber, I. (2003) América Latina, movimientos sociales y representación política (La Habana-México: Ed. Ciencias sociales).

Razavi, S. (2009) 'Engendering the political economy of agrarian change', Journal of Peasant Studies, 36(1), pp. 197-226.

Razavi, S. (2002) Shifting burdens. Gender and agrarian changes under neoliberalism (Bloomfield: Kumarian Press).

Rist, G. (1996) Le Développement, histoire d'une croyance occidentale (Paris: Presses de Sciences Po).

Rostow, W.W. (1963) 'Leading Sectors and the Take-off', in W.W. Rostow (ed.) The Economics of Take-Off into Sustained Growth (Basingstoke: Palgrave MacMillan), pp. $1-21$. 
Scott, J.W. (1986) [200o] 'Genre: une catégorie utile d'analyse historique', in J. Bisilliat and C. Verschuur (eds.) Le genre: un outil nécessaire. Introduction à une problématique (Paris: L'Harmattan), pp. 41-67.

Sen, A. (1981) Poverty and Famines: An Essay on Entitlement and Deprivation (Oxford: Clarendon Press).

Truman, H. (1949) In augural Address of the President of the United States, 20 January, https://www.trumanlibrary.org/whistlestop/50yr_archive/inagural2ojan1949.htm (accessed on 13 August 2018).

UN (United Nations) (1945) Charter of the United Nations and Statute of the International Court of Justice, https://reaties.un.org/doc/publication/ctc/uncharter.pdf (accessed on 13 August 2018).

UNDP (United Nations Development Programme) (1995) Human Development Report 1995: Gender and Human Development (New York and Oxford: Oxford University Press), http://hdr.undp.org/sites/default/files/reports/256/hdr_1995_en_complete _nostats.pdf (accessed on 9 August 2018).

UNRISD (United Nations Research Institute for Social Development) (2005) Gender Equality, Striving for Justice in an Unequal World (Geneva: UNRISD), http://www .unrisd.org/80256B3 $\mathrm{Coo}_{5} \mathrm{BCCF}$ / $/$ earch/1FF4AC64C1894EAAC1256FA3005E7201 (accessed on 9 August 2018).

Verschuur, C. (2009) 'Quel genre ? Résistances et mésententes autour du mot genre dans le développement', Revue Tiers Monde, 4(200), pp. 785-803, DOI: 10.3917/ rtm.200.0785.

Verschuur, C. and C. Catarino (eds.) (2013) Genre, migrations et globalisation de la reproduction sociale, Cahiers Genre et Développement (Geneva and Paris: L'Harmattan).

Verschuur, C., I. Guérin and H. Guétat-Bernard (eds.) (2014) Under Development: Gen$\operatorname{der}$ (Basingstoke: Palgrave Macmillan).

Wallerstein, I. (2006) Comprendre le monde. Introduction à l'analyse des systèmesmonde (Paris: La Découverte). 